\title{
Dynamics and Structure of a Field Roe Deer Population ${ }^{1}$
}

\author{
Jan KA£UZIŃSKI
}

Kałuziński J., 1982: Dynamics and structure of a field roe deer population. Acta theriol., 27, 27: 385-408 [With 9 Tables \& 10 Figs.]

The purpose of these studies was to obtain data on variations in numbers, reproduction, mortality, survival and age and sex structure. The data were collected over a period of 14 years, and using them as a basis a quantitative balance was drawn up for a population living in an agrocenosis. Average density of roe deer was 7 individuals/100 ha, and the number born was 1.9 young per female. Natural mortality among young roe deer was high $(56 \%$ of the number born) and distinctly influences effective production, the average value for which is 0.8 juv/female. Mortality among adult animals was on an average $21 \%$, varying from $7-51 \%$ of the spring numbers from the preceding year. In years which prove catastrophic for the population about $50 \%$ of the roe deer die during the first year of life. Average length of life of an individual was 3.5 years. Females predominated over males throughout the whole study period $(56: 44)$. Game shooting refered first of all to animals from $0-7$ years old from the population, and applies to $89 \%$ of males and $84 \%$ of females. Population numbers were determined by mortality among young and adult animals and by constant game shooting of about $8.1 \%$, and apart from catastrophic years exhibits a tendency to increase. Losses due to game shooting and average natural losses were effectively replenished in the study population.

[Polish Hunting Association, Research Station, 62-055 Czempiń, Poland]

\section{INTRODUCTION}

The roe deer Capreolus capreolus (Linnaeus, 1758) is a species which has comparatively recently settled numerously in cultivated fields in Poland (Pielowski, 1970, 1977; Kałuziński, 1974, 1978; Bresiński, 1982), hence the need for detailed studies on the functioning of the roe deer populations living in a habitat new to them.

The numerous occurrence of roe deer in an agricultural habitat intensively cultivated and shaped by man, constitutes an important ecological problem from many points of view. One of these is the possibility of examining the adaptation of a large herbivore to new habitat conditions. In addition roe deer populations in agrocenoses to some extent constitute a model system, since they create the opportunity for tracing the course of the ecological phenomena arising as the result

${ }^{1}$ Praca wykonana w ramach problmu MR-II/15 koordynowanego przez Instytut Ekologii PAN. 
of human activities and controlled natural conditions. The open field habitat provides opportunities for easy observations of a considerable number of important parameters in roe deer populations such as numbers, reproduction, sex structure and mortality. By obtaining a throughout knowledge of the basic properties of these populations it is possible to define their functioning in a agrocenosis.

The purpose of this study is to examine variations in numbers, reproduction and mortality, sex and age structure and the survival of individuals in roe deer populations living in agrocenoses. A quantitative balance was drawn up, which permitted of tracing the functioning of the population over a long-term period. The results obtained may contribute to rational utilization of the resources of this species.

\section{STUDY AREA}

The studies were carried out in the experimental area of the Polish Hunting Association Research Station at Czempiń, in the Poznań voivodship, covering an area of 15,000 ha, out of which area the habitat in which roe deer live consists of 13,5 thousand ha, 1000 ha of which is wooded land. This consists of shelterbelts varying in size from 50 to 300 ha, situated in six groups on the boundaries of the study area. The predominant biotope in these woods is coniferous forest, with pine as the main structural element of treestands.

The area is almost entirely flat, with large stretches of fields under intensive cultivation. The level of agricultural mechanization there and the degree of chemical plant protection is high for Polish conditions.

The area is transected by numerous roads and drainage ditches, most of which are lined by shrubs and trees. In addition there is a large number of shelterbelts of different kinds in fields, constituting coverts, osier plantations, unfenced orchards, small depressions in the area where humidity is greater and which are overgrown by reeds and shrubs, with trees and Helianthus tuberosus on the fringes. The average degree of cover provided by wooded land of various types in the fields and other shelters for game animals was $1.9 \%$ (Bresiński \& Chlewski, 1975), but they are not evenly distributed. The dominating species of trees in shelterbelts and coverts in the upper layer were: willow, acacia, alder, birch, poplar, oak and maple. In the lower elder, hawthorn, field maple, blackthorn, privet, snowberry, evonymus, hazel and single other shrubs. The edge of shelterbelts is most often covered by grass and weeds. The verges of the majority of the roads are planted with rows of single deciduous and fruit trees. The food resources for roe deer have been estimated as very good in this area. During the winter, and particularly when the ground is covered with snow, the roe deer are given supplementary feeding with hay from papilionacous plants and fodder cabbage. The animals are supplied with salt over the whole year in numerous licks evenly distributed over the area. There are few ponds or streams there. Two railroads run through the area, on one of which there is intensive traffic by fact electric trains. An important feature of this area is the compact building of hamlets, often at considerable distances from each other. The area is under the protection of permanent employess who are under and obligation to control stray dogs, which may constitute indirect, or even direct, danger for roe deer. Among predators 
which are capable of affecting population numbers are foxes Vulpes vulpes (Linnaeus, 1758), the average numbers of which over a year in the study area are about 43 individuals. Other factors directly limiting population numbers are traffic, both road and rail, and harvesting by means of machines and agricultural equipment (Kałuziński, 1982).

Average game utilization was $8.1 \%$ of the spring numbers of adult animals and $1.4 \%$ of young, i.e. during the year of their birth. Maximum utilization in one year was $14.6 \%$ of adult animals and $5.5 \%$ of young, and corresponding minimum $2.0 \%$ of both these categories. Among adult animals average utilization of bucks was about $10.0 \%$, and does $6.7 \%$, of their numbers. The general principle for obtaining bucks was selective shooting of individuals, the antlers of which differ from the established normal pattern in different age classes. Does were shot at random.

\section{METHODS}

\subsection{Estimating Numbers}

The studies were carried out from 1966-1980. Numbers were determined by the methods of direct observation of individuals. The grouping of roe deer in herds in fields during late autumn, winter and spring periods provides opportunities for accurately establishing numbers (Bresiński, 1982).

Numbers were estimated by three people moving over marked parts of the area, counting roe deer in open parts of the area and driving in all coverts in fields. Numbers of roe deer were counted every year towards the end of winter, at the end of February or early in March, usually when the weather was sunny, making it possible accurately to observed herds or single individuals, using a binocular telescope $40 \times 80$ or field glasses $15 \times 50$.

In addition to counts made in fields and coverts, the number of roe deer was also counted in feeding places during the time the animals emerge from woods in the evening or early morning, using 8-10 observers. Details of counts of roe deer in small wooded areas have been given by Pielowski \& Bresiński (1982).

\subsection{Reproduction}

Reproductive potential was defined by macroscopic examination of the uteri of females shot during the last ten days of January or in February. The age of the females was determined, which made it possible to obtain data on their fecundity depending on age. The numbers of fawns which would have been born in the study area was obtained from the number of embryos per female, multiplied by the number of females more than one year old. Yearling does do not usually take part in reproduction. In calculations at population level the average reproductive potential of females for the whole study period was accepted. The duration of the period when does drop their fawns was estimated on the basis of newborn fawns found when harvesting green fodder, which was carried out in May and June over a relatively extensive area (Kałuziński, 1982).

\subsection{Mortality}

Mortality among young animals was calculated every year from the difference in the number born and effective production found, i.e. the number of individuals 
surviving the first winter, taking into account the small number of fawns recorded as shot in autumn.

Calculation was made from the difference of numbers of roe deer in spring in successive years and allowing for the number shot, of losses of adult individuals, separately for bucks and does. With the present state of knowledge of this population it was difficult to determine what percentage of natural losses is formed by migrations. It was assumed that emigration and imigration of roe deer take place to similar degrees, since this agrees with the generally accepted principles for procedure in investigations of mortality in a population (Petrusewicz, 1978).

In order to obtain more accurate data on mortality in the population information was collected on dead individuals found in the study area. Particularly large numbers were found in $1978 / 79$, which was distinguished by exceptionally heavy winter losses. Age and sex structure was established for dead individuals.

\section{3,4. Survival}

The roe deer which died in 1978/79 constituted a sample which was used to draw up survival tables by Caughley's method for the animals in the study population (1977). Although these were only winter losses (and in this case there are some doubts as to applying this method) the number of dead animals was so great $(n=889)$, that this event was considered exceptional. The suitability of this method was also borne out by the fact that during the preceding period the population had been characterized by stable age structure, and its growth index was also known.

\subsection{Sex and Age Structure}

Every year during the period for estimating population numbers of roe deer, sex ratio was determined in the classes of adult and young individuals. The direct sex dimorphism present made it possible to carry out accurate evaluation of sex in the roe deer, using good field glasses.

Age was defined in all the roe deer shot, on the basis of degree of wear of the premolar and molar teeth (Pielowski, 1970; Rieck, 1970), with accuracy to two years. In order to render these estimates even more accurate age was determined by the method of grinding in 37 individuals chosen at random (Hell et al., 1973; Aitken, 1975). The microscopic pictures obtained did not always permit of defining exactly the number of annual layers of cementum, and this may to some extent have been due to the relatively mild winters in the western regions of Poland.

Investigated animals were killed by hunters and it was the other difficulty in age determination because hunting period was widen in a year (males) MaySeptember; females, October-January). In consequence of it the youngest killed male was about 12 months old and the youngest female - about 20 months old. Situation in older animals group was similar. Considering unaccuracy of used method and differences in hunting period for males and females, age was determinated in following classes $1-2,2-3,3-4$ and so on. Classes overlap, but each individuals is in one class only. Adjoining classes were combined sometimes for statistics purposes. 


\section{RESULTS}

\subsection{Numbers}

During the fourteen successive study years there were two periods of abrupt decrease in the numbers of the roe deer population. The first of these periods lasted two years. In 1969/70 decrease in numbers was $35 \%$ of the spring head of roe deer and decreased by a further $36 \%$ in the following year. In $1978 / 79$ population numbers dropped by $51 \%$. The direct cause of such great decreases in population numbers was in both cases the difficult winter conditions, greatly differing from the average for this part of Poland. Details of this are to be found in section 4.3 .

The changes observed in population numbers in different years depend directly on the natural mortality of adult and young animals. Shooting exerts only a negligible influence on the state of the population. In $1975 / 76$ and $1976 / 77$ the number of adult animals shot was the greatest

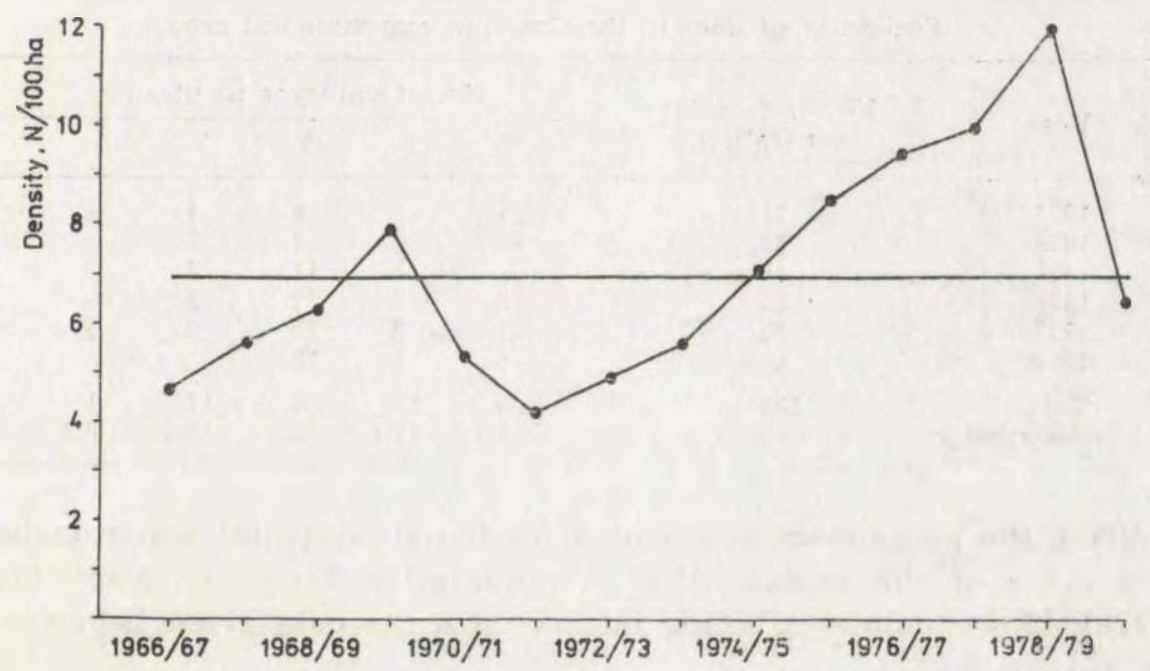

Fig. 1. Density of roe deer in the Czempiń experimental area from 1966-1980.

for the whole study period, being respectively $14.6 \%$ and $12.2 \%$ of the spring head of roe deer, and this reduced the rate of increase in population numbers.

Average density from $1966-1980$ was $7(4.2-12.0)$ individuals per 100 ha (Fig. 1). In reality roe deer are not distributed evenly over the area and there is a natural tendency for them to gather in herds during the autumn, winter and spring (Pielowski, 1970, 1977; Kałuziński, 1974; Bresiński, 1982). 


\subsection{Reproduction}

The number of embryos in the does of reproductive age examined (more than 21 months old) was on an average 1.88 (138 $q: 160$ embryos) per female.

The phenomenon of resorption of embryos is very rare in roe deer. Strandgaard (1972) described one such case. It may therefore be assumed that the number of embryos greatly advanced in development in uteri corresponds to what is termed total fecundity and is similar to the number born.

The number of embryos in the roe deer uteri inspected was from $0-4$ embryos. Most often, in $68 \%$ of all the uteri, there were 2 embryos, about $12 \%$ with one embryo and with 3 , and in one case four embryos was made of the reproductive potential after Seviercov, (after Trojan 1978). It was 1.89 and taking into account the data given below

Table 1

Fecundity of does in the Czempin experimental area.

\begin{tabular}{|c|c|c|c|c|c|c|}
\hline \multirow{2}{*}{ Year } & \multirow{2}{*}{$\begin{array}{l}\text { No. of females } \\
\text { controlled }\end{array}$} & \multicolumn{5}{|c|}{ No. of embryos in uterus } \\
\hline & & 0 & 1 & 2 & 3 & 4 \\
\hline 1973 & 11 & 1 & - & 6 & 4 & - \\
\hline 1974 & 12 & - & 4 & 7 & 1 & - \\
\hline 1975 & 18 & - & 1 & 11 & 6 & - \\
\hline 1976 & 25 & 2 & 3 & 17 & 2 & - \\
\hline 1977 & 32 & 1 & 3 & 25 & 2 & 1 \\
\hline 1978 & 40 & 5 & 6 & 28 & 1 & - \\
\hline Total & 138 & 9 & 17 & 94 & 17 & 1 \\
\hline Percentage & & 6.5 & 12.4 & 68.1 & 12.3 & 0.7 \\
\hline
\end{tabular}

Using the parameters determined for the study population calculation was made of the reproductive potential after Seviercov, after Trojan (1978). It was 1.89 and taking into account the data given below

where: $q$ - reproductive potential,

$$
q=\sqrt[p \cdot j \cdot s]{r+1}
$$

$r-$ number of young in litter $=1.9$,

$p-$ period between litters in years $=1$ year,

$j$ - age at which sexual maturity is reached $=1.3$ years,

$s$ - ratio of males to females $=1.28$.

The fact is remarkable that the reproductive potentials calculated (1.89), and obtained by means of inspecting uteri (1.88), are similar. This may point to the favourable living conditions of the population. 
The females' capacity for reproduction is retained into their old age but the most productive are does from 2-7 years old (Table 2).

Fecundity decreases with age and is greatest in does from $4-5$ years old (2.54 juv) and lowest in old does 10-years or over (Table 2). Despite this distinct decrease of $40 \%$ in fecundity, no significant difference was found in the fecundity of does up to 7 years of age and over.

Table 2

Number of embryos per statistical female in different age classes. $t=2.221 \quad i>0.05$

\begin{tabular}{|c|c|c|c|c|}
\hline \multirow{2}{*}{$\begin{array}{l}\text { Age } \\
\text { class }\end{array}$} & \multirow{2}{*}{$\begin{array}{l}\text { No. of } \\
\text { females }\end{array}$} & \multicolumn{2}{|c|}{ Number of embryos } & \multirow{2}{*}{ Avg. } \\
\hline & & $\mathrm{n}$ & per female & \\
\hline & 5 & 10 & 2.00 & \\
\hline $2-3$ & 39 & 69 & 1.77 & \\
\hline $3-4$ & 32 & 64 & 2.00 & \\
\hline $4-5$ & 11 & 28 & 2.54 & \\
\hline $5-6$ & 18 & 36 & 2.00 & \\
\hline $6-7$ & 6 & 12 & 2.00 & 2.05 \\
\hline $7-8$ & 9 & 16 & 1.78 & \\
\hline $8-10$ & 11 & 19 & 1.73 & \\
\hline$>10$ & 5 & 8 & 1.60 & 1.70 \\
\hline
\end{tabular}

One of the important factors determining the reproductive success of the population is the season of the year in which reproduction takes place. Under field conditions it is difficult to define accurately the season during which does drop their young. In a field habitat does give birth in the dense vegetation of cultivated fields, and thus it is an almost impossible task to find the young fawns. The only data were obtained during the spring green fodder harvest. From 1976-1980, during the period from 15th May and 20th June, 129 observations were made of 129 newborn fawns. Of this number 57 were born between 15 th -30 th May, and 72 individuals between 1st-20th June. As the area inspected in these two periods was similar, it may be assumed that more fawns are born in June than in May. Among the fawns found in June 33 were born between the 16 th-20th of that month, which points to marked intensity of births during the second 10-day period of June. It may therefore be concluded that the period in the study year during which does give birth was relatively long. The young are born in May, June and certainly also at the beginning of July. Peak birth period is between 15th May and 25th June.

Effective production among roe deer was defined as the ratio of young animals which survived the first winter of their lives to the number of females capable of reproduction. In different reproduction seasons 
this production varied from 0.1 to 1.4 , and was on an average 0.8 individuals/ $q$ taking part in reproduction (Table 3). Effective increase is far lower if it is referred to all females in the spring population, when it is then only $0.56 /$ o (Table 8 ).

Table 3

Effective production in the roe deer population living in the Czempin experimental range.

\begin{tabular}{|c|c|c|c|c|}
\hline \multirow{2}{*}{ Year } & \multirow{2}{*}{$\begin{array}{l}\text { No. of does } \\
\text { taking part in } \\
\text { reproduction }\end{array}$} & \multirow{2}{*}{$\begin{array}{l}\text { No. } \\
\text { of young }\end{array}$} & \multicolumn{2}{|c|}{ Realized production } \\
\hline & & & $\mathrm{n}$ & per female \\
\hline $1966 / 67$ & 269 & 511 & 221 & 0.8 \\
\hline $1967 / 68$ & 343 & 651 & 246 & 0.7 \\
\hline $1968 / 69$ & 373 & 706 & 304 & 0.8 \\
\hline $1969 / 70$ & 456 & 868 & 71 & 0.1 \\
\hline $1970 / 71$ & 397 & 746 & 163 & 0.4 \\
\hline $1971 / 72$ & 262 & 497 & 201 & 0.8 \\
\hline $1972 / 73$ & 272 & 651 & 220 & 0.8 \\
\hline $1973 / 74$ & 317 & 602 & 363 & 1.1 \\
\hline $1974 / 75$ & 321 & 611 & 326 & 1.0 \\
\hline $1975 / 76$ & 457 & 870 & 482 & 1.0 \\
\hline $1976 / 77$ & 416 & 756 & 479 & 1.1 \\
\hline $1977 / 78$ & 431 & 782 & 601 & 1.4 \\
\hline $1978 / 79$ & 543 & 1031 & 223 & 0.4 \\
\hline $1979 / 80$ & 360 & 684 & 295 & 0.8 \\
\hline Avg. & 381 & 711.4 & 299.6 & 0.8 \\
\hline
\end{tabular}

4.3. Mortality

Mortality among the young animals in the study population is a variable value. Over the 14-year study period mortality was lowest in $1973 / 74$ and $1977 / 78$, respectively about $38 \%$ and $21 \%$ of the number born. Maximum mortality among young roe deer, on the other hand, was observed in $1969 / 70(90 \%)$ and $1978 / 79(77 \%)$. On an average $44 \%$ of the total number of fawns born survive their first winter (Fig. 2).

Average annual mortality among adult individuals for the long-term study period was approximately $21 \%$ of the spring numbers. In different years there are distinct differences. In favourable years mortality among adult animals was $50 \%$ lower than the average value, but in the critical years $1969 / 70$ and $1978 / 79$ corresponding mortality was $35 \%$ and $51 \%$ of total numbers. It is also characteristic that in the year following every catastrophic year for the population, far higher mortality was observed than the average.

Every year records were kept of dead individuals, collecting whenever possible more detailed data on their age, sex, date and cause of death. These investigations, however, with the exception of $1978 / 79$, were in 
principle limited to accidental finds of dead animals, nevertheless from $16.5 \%$ to $65.5 \%$ of the total number of animals lost apart from shooting were found in this way, giving a combined total of $34 \%$ (Table 4 ). This was possible owing to the specific nature of the field habitat which

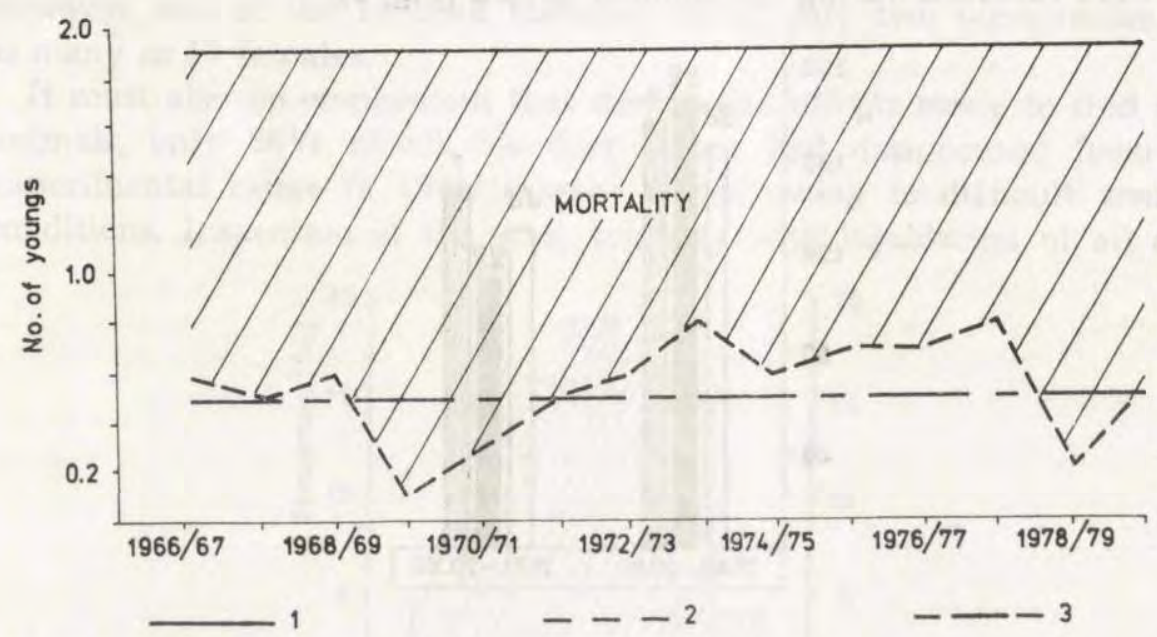

Fig. 2. Variations in mortality of young roe deer in Czempin experimental area from 1966-1980. (1) average number of young born by 1 , (2) effective production per statistical female, (3) average effective production per female.

Table 4

Number of dead roe deer found in the study area $\left(x_{1}\right)$ and calculated from balance $\left(x_{2}\right)$.

\begin{tabular}{crrc}
\hline Year & $x_{1}$ & $x_{2}$ & $x_{1} / x_{2} \%$ \\
\hline $1966 / 67$ & 19 & 95 & 20.0 \\
$1967 / 68$ & 27 & 106 & 25.4 \\
$1968 / 69$ & 27 & 68 & 39.7 \\
$1969 / 70$ & 246 & 378 & 65.0 \\
$1970 / 71$ & 44 & 262 & 16.8 \\
$1971 / 72$ & 23 & 71 & 32.4 \\
$1972 / 73$ & 15 & 44 & 34.1 \\
$1973 / 74$ & 27 & 129 & 20.1 \\
$1974 / 75$ & 29 & 75 & 38.6 \\
$1975 / 76$ & 31 & 177 & 17.5 \\
$1976 / 77$ & 37 & 227 & 16.5 \\
$1977 / 78$ & 60 & 159 & 37.7 \\
$1978 / 79$ & 304 & 835 & 36.4 \\
Avg. & 68.4 & 202.0 & 33.8 \\
\hline
\end{tabular}

in spring, autumn and winter is devoid of tall vegetation. During the study period a combined number of 889 animals were found, $57 \%$ of which had died in winter and $43 \%$ during the other three seasons of the year. Winter deaths are more numerous than summer ones and 
in years catastrophic to roe deer may even be as much as approx. $80 \%$ of total annual mortality. Although it was found that during the winter period $47 \%$ were bucks and $53 \%$ does among the dead roe deer found, this is not evidence of greater mortality among females, since proportions were reversed during the summer period (Fig. 3).

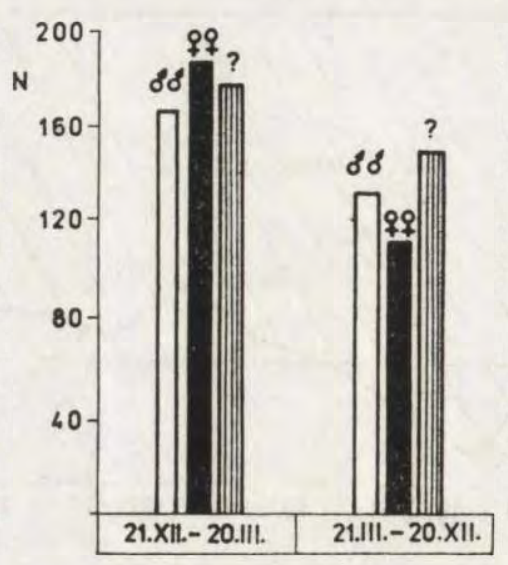

Fig. 3. Number of dead roe deer found in winter and during plant growing season. Question mark indicates animals for which sex could not be established.

\section{Table 5}

Distribution of mortality among roe deer during the winter of $1978 / 79$ depending on age.

Percentage for age class 1 is 49.8 and for age classes $1-2$ to $9-10=50.2$

\begin{tabular}{lrcr}
\hline Age class & Males & Females & Total \\
\hline$<1$ & 67 & 50 & 117 \\
$1-2$ & 4 & 2 & 6 \\
$2-3$ & 3 & 5 & 8 \\
$3-4$ & 4 & 7 & 11 \\
$4-5$ & 6 & 5 & 11 \\
$5-6$ & 5 & 7 & 12 \\
$6-7$ & 5 & 7 & 12 \\
$7-8$ & 9 & 9 & 18 \\
$8-10$ & 12 & 13 & 15 \\
$>10$ & 2 & 13 & 25 \\
Age index & 17 & 8 & 44 \\
Age \& sex index & 134 & 126 & 304 \\
Total & & & \\
\hline
\end{tabular}

Exceptionally great losses of roe deer were observed in the winter of 1978/79. Among all the roe deer found for which age was established, as many as $50 \%$ were individuals in the first year of life. Relatively great losses were also observed in the oldest age classes, but lowest mortality was characteristic of the medium age classes (Table 5). 
No statistically significant differences were found in mortality of males and females in the whole material, consisting of 260 dead roe deer, for which it proved possible to distinguish sex, or among the young individuals in age class I (Student $t$ test, $P<0.05$ ). In the final age class, however, out of the 15 dead roe deer found only two were males and as many as 13 females.

It must also be emphasized that despite the efforts made to find dead animals, only $38 \%$ of all roe deer which had disappeared from the experimental range in 1978/79 were found, owing to difficult weather conditions. Inspection of the area, together with liquidation of all dead

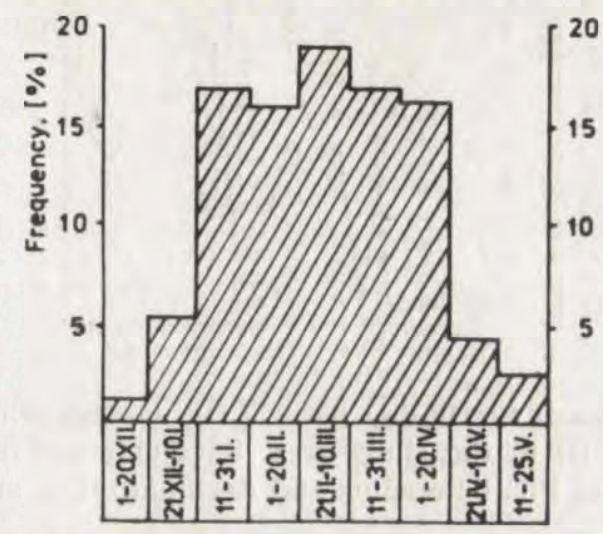

Fig. 4. Natural mortality in a population of field roe deer in the Czempin experimental area during the winter of 1978/79.

animals found, was carried out systematically, which made it possible to draw conclusions as to the course and duration of such natural losses. The period of intensive losses lasted about 100 days and was maintained over the whole period a similar level. Only a slight increase in mortality was found between 21st February and 10th March, that is, in the middle of the period of intensified losses. An abrupt increase, followed by a similarly abrupt decrease, in this phenomenon is a characteristic feature (Fig. 4).

When analyzing the weather factors prevailing during this period in the study area it is possible to descry a distinct relation between them and the course taken by mortality in the roe deer population. During the first 10 days of January average temperature fell to approximately $-13^{\circ} \mathrm{C}$ and snowfall intensified, resulting in a snow cover of about $15 \mathrm{~cm}$ over most of the study area, while the wind blew with a velocity of about $2.8 \mathrm{~m} / \mathrm{sec}$. The effect of these factors for a period of 'about 10 days is reflected in the losses of roe deer (Fig. 4 and 5). Although the temperature remained at approximately $-6^{\circ} \mathrm{C}$ during the 
following two 10-day periods of January and for the two subsequent 10-day periods of February, the wind increased in strength to reach a velocity of about $7 \mathrm{~m} / \mathrm{sec}$ towards the end of the second 10-day period of February. Snow cover, composed of several layers, increased in thick-

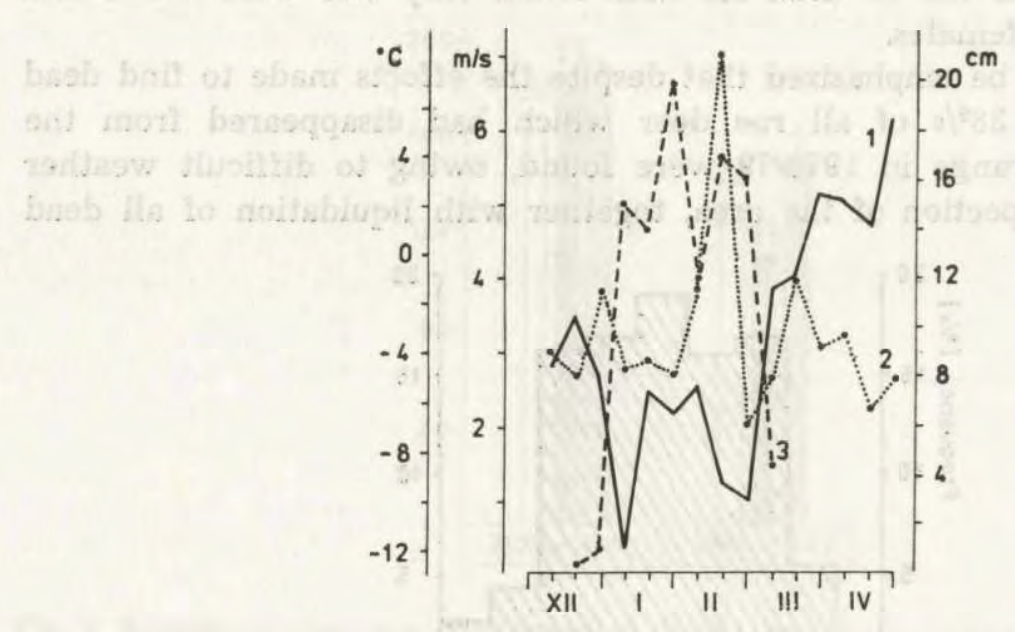

Fig. 5. Average temperatures for 10-day periods (1), average wind velocity (2) and thickness of snow cover (3) in the study area. Data-obtained from the Station of the Institute of Plant Breeding and Acclimatization at Borów.

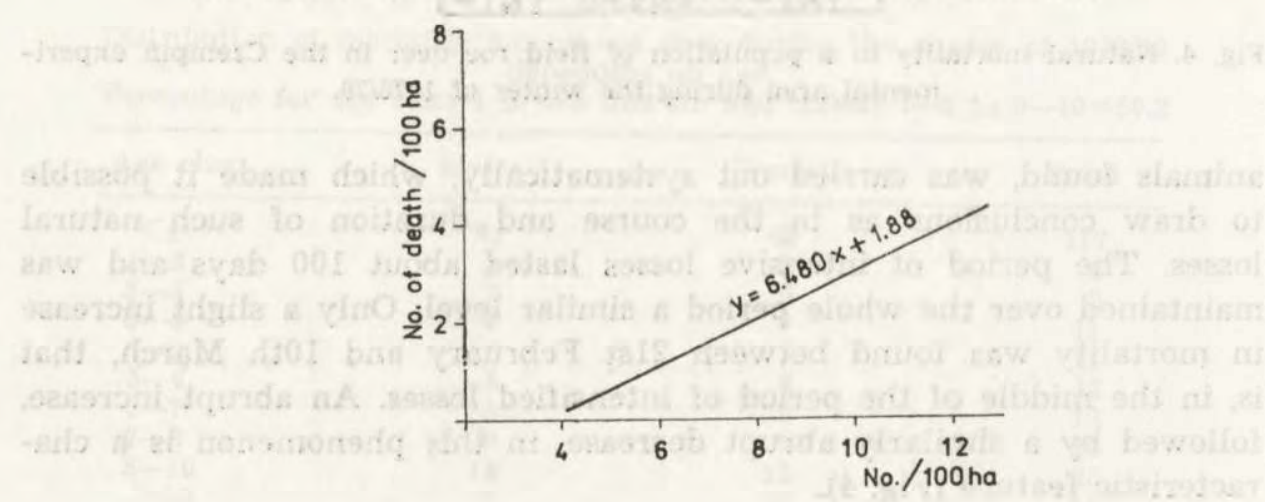

Fig. 6. Effect of population density on mortality among adult animals.

ness and compactness to about $20 \mathrm{~cm}$. During the third 10-day period of February, after a very windy period, the temperature again dropped to an average of about $-10^{\circ} \mathrm{C}$ and during the time these weather conditions persisted mortality among roe deer reached a maximum (Fig. 4 and 5). In March all three weather factors examined clearly improved, but even so their unfavourable effects on roe deer continued to be felt and the period of intensified precipitation lasted to April 30 . 
A significant positive relation was found between population density and losses in herd of roe deer $(r=0.726 ; i=0.01 ; t=3.667)$ (Fig. 6).

\subsection{Survival}

On the basis of material collected relating to mortality among roe deer in 1978/79, a survival table was drawn up for individuals in this population (Table 6), assuming that increased mortality during that season exerted a similar effect on population parameters as in other years, and that the difference consisted only in the degree of their effect. The mean length of life of roe deer is approximately 3.5 years and only occasional individuals live longer than 10 years.

Table 6

Survival table for roe deer based on 889 dead animals found during the winter $x$, number of age class of $1978 / 79$.

$d x_{1}$, number of animals dying in the given age class

$x_{1}$, number of animals surviving to given age

$x$, number of animals surviving to beginning of age class converted so that 10 represents 1000

$d_{x}$, number of animals dying in age class $x$

$q_{x}$, index of mortality, probability that an individual surviving to the beginning of an age class died in the same class

$L_{x} T_{x}$, auxiliary values in calculating $e_{x}$

$e_{x}$, anticipated life expectancy

$L_{x}$, approximate number of individuals surviving to middle of age class.

\begin{tabular}{rrrrrrrrrr}
\hline$x$ & $\begin{array}{c}\text { Age } \\
\text { class }\end{array}$ & $d x_{1}$ & $x_{1}$ & $x$ & $d_{x}$ & $q_{x}=\frac{d x}{l x} 100$ & $L_{x}$ & $T_{x}$ & $e_{x}$ \\
\hline 0 & $0-1$ & 117 & 235 & 1000 & 498 & 0.49 & 751 & 3438 & 3.44 \\
1 & $1-2$ & 6 & 118 & 502 & 26 & 0.05 & 489 & 2687 & 5.35 \\
2 & $2-3$ & 8 & 112 & 476 & 34 & 0.07 & 459 & 2198 & 4.62 \\
3 & $3-4$ & 11 & 104 & 442 & 34 & 0.07 & 418 & 1739 & 3.93 \\
4 & $4-5$ & 11 & 93 & 395 & 47 & 0.12 & 372 & 1321 & 3.34 \\
5 & $5-6$ & 12 & 82 & 349 & 46 & 0.13 & 323 & 949 & 2.72 \\
6 & $6-7$ & 12 & 70 & 297 & 52 & 0.17 & 271 & 626 & 2.10 \\
7 & $7-8$ & 18 & 58 & 246 & 51 & 0.20 & 208 & 355 & 1.44 \\
8 & $8-10$ & 25 & 40 & 170 & 76 & 0.44 & 116 & 147 & 0.86 \\
10 & 10 & 15 & 15 & 63 & 107 & 1.69 & 31 & 31 & 0.49 \\
15 & 15 & 0 & 0 & 0 & 63 & - & 0 & 0 & - \\
\hline
\end{tabular}

\subsection{Sex and Age Structure}

The numerical predominance of females over males in the roe deer population was maintained over the whole study period. Shooting activities up to 1974/75 had only a slight effect on the sex ratio prevailing in the population. Average game shooting during this time was $5.5 \%$ of the number of adult animals. This applied to a greater extent to 
males $-6.4 \%$, than to females $-4.8 \%$. Fawns were shot on a level of about $1 \%$ of their numbers. Game shooting on this low level had no important effect on the sex ratio in the population.

From $1975 / 76$ to $1977 / 78$ shooting increased to about $14 \%$ of the spring numbers of the roe deer population and during this time on an average only $0.4 \%$ more of males were shot than females. The numerical predominance of females over males was evident in the population. In $1978 / 79$, when shooting structure was again unbalanced (about $13 \%$ of total numbers of males were shot, and about $4.5 \%$ females) there was a return to the state which had previously existed (Table 7). Sex structure over the whole study period was on an average $1: 1.28$ in favour of females.

Table 7

Sex structure in the roe deer population living in the experimental area.

\begin{tabular}{crccc}
\hline & & & & ad Females \\
\cline { 4 - 5 } Year & $N$ & Males & Females & ad Males \\
\hline $1966 / 67$ & & 273 & 369 & 1.35 \\
$1967 / 68$ & 642 & 288 & 468 & 1.62 \\
$1968 / 69$ & 756 & 349 & 512 & 1.46 \\
$1969 / 70$ & 861 & 437 & 630 & 1.44 \\
$1970 / 71$ & 1067 & 281 & 433 & 1.54 \\
$1971 / 72$ & 714 & 215 & 355 & 1.65 \\
$1972 / 73$ & 570 & 279 & 386 & 1.38 \\
$1973 / 74$ & 665 & 326 & 442 & 1.35 \\
$1974 / 75$ & 768 & 515 & 512 & 1.23 \\
$1975 / 76$ & 927 & 613 & 643 & 1.21 \\
$1976 / 77$ & 1173 & 664 & 675 & 1.09 \\
$1977 / 78$ & 1285 & 764 & 865 & 1.03 \\
$1978 / 79$ & 1349 & 394 & 482 & 1.12 \\
$1979 / 80$ & 1626 & 416 & 533 & 1.23 \\
Avg. & 881 & 43.8 & 56.2 & 1.28 \\
Per cent & 949 & & & - \\
\hline
\end{tabular}

During the period of embryonic development sex ratio is balanced and sometimes there is a minimal predominance of male individuals (Borg, 1970; Prior, 1968; Strandgaard, 1972). It is interesting that in the case of the study population of roe deer a distinct predominance $(1: 1.3)$ of females was found among fawns on their first day of life $(n=138)$, similar to the average sex ratio among adult individuals. This sex ratio was maintained among fawns still keeping with does as from early autumn (Kałuziński, 1978). The predominance of females observed in the study population is thus conditioned not only by game shooting, but also by ecological factors.

During the study period age was determined in a joint total of 1092 shot individuals, 578 being males and 514 females. When the shot roe 
deer were divided into five age classes, an unequal distribution was obtained. It was found that roe deer from $1-3$ years old are most intensively shot, more females being shot than males. It is in principle chiefly the first three age classes which are shot, which forms $89 \%$ of males and $81 \%$ of females. Attention must also be drawn to the considerable differences between shooting of males (about $0.7 \%$ ) and

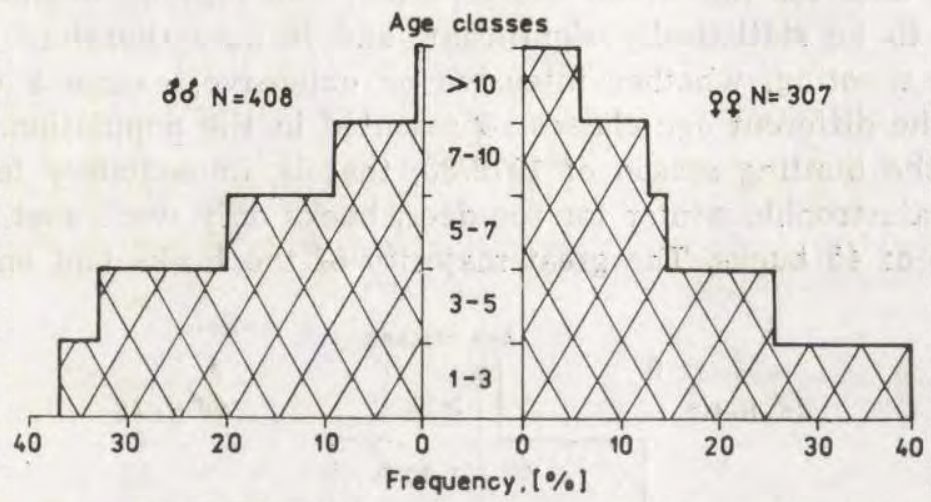

Fig. 7. Age structure of roe deer shot in Czempin experimental area from 19661975 and $1979-1980$.

Test of homogeneity $\chi^{2}=27.3, \alpha=0,01, r=4$

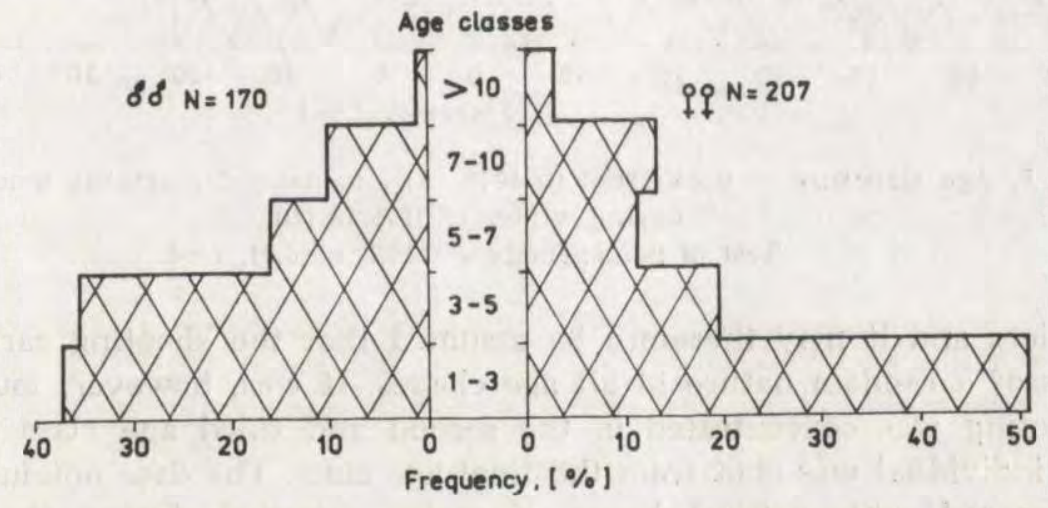

Fig. 8. Age structure of roe deer shot in Czempiń experimental area from 1976-1978.

Test of homogeneity $\chi^{2}=16.6, \alpha=0.01, r=4$

females (about $3 \%$ ) in relation to total shooting of one and the other in the oldest age class. Differences in the number of males and females shot in different age classes are significant, and consequently the age structure of the males shot cannot be considered as identical with relevant data for females (Fig. 7). 
The relatively large number shot from 1976-1978 did not level up these differences (Fig. 8). The distribution of intensive shooting during these years is similar to that for the whole study period (cf. Fig. 7 and 8). Using the chi-square test for homogeneity examination was also made of the relation between the number of males and females shot in different age classes, during years of intensive shoots, with the corresponding data for the whole study period. The relation examined did not prove to be statistically significant, and it may therefore be said that game shooting, whether intensive or extensive, exerts a uniform effect on the different age classes represented in the population.

During the hunting season of $1979 / 80$, that is, immediately following upon the catastrophic winter for roe deer, bucks only were shot, obtaining a total of 45 bucks. The great majority of the bucks had only poor

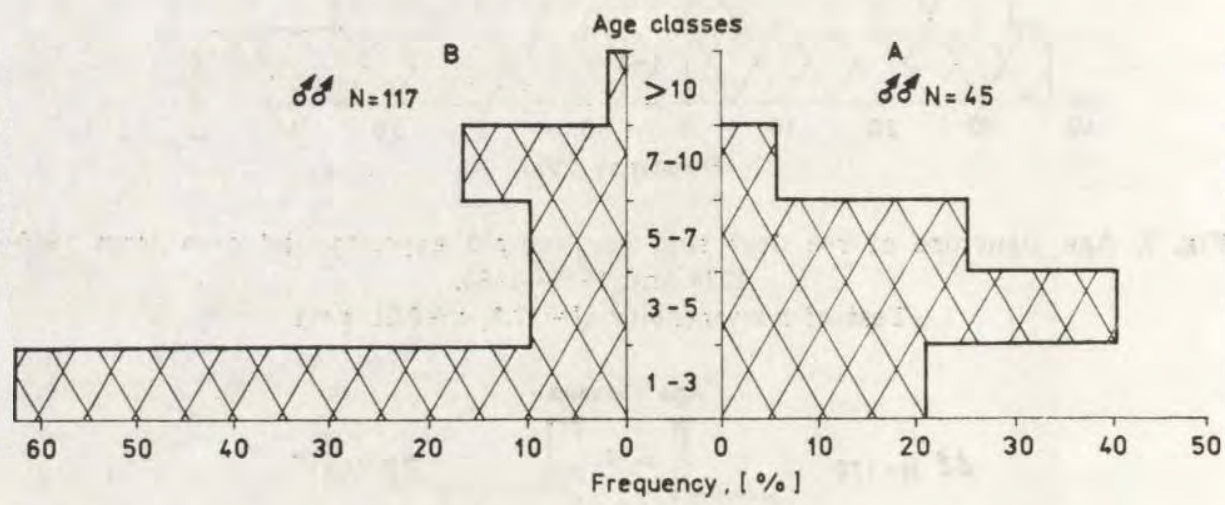

Fig. 9. Age structure of bucks shot in 1979 (A) and natural mortality among bucks during winter of $1978 / 79$ (B).

Test of homogeneity $\chi^{2}=44.7, \alpha=0.01, r=4$

antlers and it may therefore be assumed that the shooting carried out was of a random nature in all age classes. It was, however, found that shooting was concentrated in the second and third age class (Fig. 9). No individual was shot from the final age class. The data obtained were compared with natural losses of males recorded during the winter preceding the shooting. It was found that $71 \%$ of the animals shot belonged to the age class which had suffered the least losses during the winter period.

The age pyramids drawn up for the animals shot are similar to the theoretical age structure given in literature for roe deer populations (Trojan, 1978) and also to the age structure of the population estimated by means of complete elimination by shooting (Pielowski \& Bresiński, 1982). 


\subsection{Annual Numerical Balance for the Population}

The most important basis for rational management of population productivity is to draw up an annual balance of increase in numbers and losses. With such data it is possible to establish, inter alia, an extent of game shooting, the purpose of which is to preserve the basic herd, and ensure permanent utilization distributed in time. The annual quantitative balance of the population may be constructed if the numbers of spring herds before the reproduction period in consecutive years are known. In effect the balance represents successive stages of reduction of potential increase, indicates where reduction takes place, how great it is in different stages and what effect this has on the spring population numbers.

The average annual balance for the population was obtained from the parameters discussed previously (Table 8). It was found that the

\section{Table 8}

Mean annual balance for the roe deer population for the period 1966-1980.

\begin{tabular}{|c|c|c|c|c|}
\hline Parameters & Sex & & $\pm S D$ & Indexes \\
\hline \multirow{2}{*}{ State of population in April } & $\underset{\mathrm{F}}{\mathrm{M}}$ & $\begin{array}{l}415 \\
534\end{array}$ & & $44 \%$ \\
\hline & $M+F$ & 949 & & $7.0 \pm 2.29 / 100$ ha \\
\hline $\begin{array}{l}\text { Number of females taking part } \\
\text { in reproduction }\end{array}$ & & 374 & $( \pm 76.72)$ & $70 \%$ \\
\hline \multicolumn{2}{|l|}{ Number of fawns born } & 711 & $( \pm 145.77)$ & $1.9 / 1 \mathrm{~F}$ \\
\hline \multicolumn{2}{|l|}{$\begin{array}{l}\text { Natural mortality juv } \\
\text { Harvest juy }\end{array}$} & 402 & $( \pm 193.24)$ & $56 \%$ \\
\hline \multicolumn{2}{|l|}{ Harvest juv } & 10 & $( \pm 11.64)$ & $1.4 \%$ \\
\hline \multicolumn{2}{|l|}{ Realized production for March 31th } & 299 & $( \pm 142.22)$ & $0.8 / \mathrm{F}$ \\
\hline \multirow[t]{2}{*}{ Harvest of adult individuals } & M & 41 & & $10.0 \%$ \\
\hline & $M+F$ & $\begin{array}{l}30 \\
77\end{array}$ & $( \pm 59.28)$ & $8.1 \%$ \\
\hline \multirow[t]{3}{*}{ Natural loss of adult } & $\mathrm{M}$ & 85 & & $20 \%$ \\
\hline & $F$ & 117 & & $22 \%$ \\
\hline & $M+F$ & 202 & $( \pm 203.92)$ & $21 \%$ \\
\hline \multirow{2}{*}{ State for March 31th next year } & $\begin{array}{c}\mathrm{M} \\
\mathrm{F}\end{array}$ & $\begin{array}{l}289 \\
381\end{array}$ & 969 & $\begin{array}{l}30 \% \\
39 \%\end{array}$ \\
\hline & $M+F$ & 299 & & $31 \%$ \\
\hline
\end{tabular}

annual average population increase for the period $1966-1980$ is slight, since the difference in spring numbers in consecutive years ( $\triangle N$ $(949: 969)=2 \%$.

In order to examine the effect on numbers of: (1) numbers of females taking part in reproduction, (2) number of fawns born, (3) natural mortality among fawns, (4) shooting of fawns, (5) realized production, (6) shooting of adult individuals, (7) natural losses among adult roe deer, these parameters were examined by multiple regression analysis with 
choice of the best subcollection from the above mentioned independent variables. It was found that only realized production has any important influence on density. Variable (7) was on the borderline of significance. Using the same multiple regression analysis of variables, examination was made of the effect of density on the state of these variables in the following year. It was found that density exerts a significant effect only on realized production. Equations of regression from the first and second assumption have been given in diagram form. The straight lines plotted take a slightly similar course, which may suggest that realized production is greater when density is greater, and vice versa (Fig. 10).

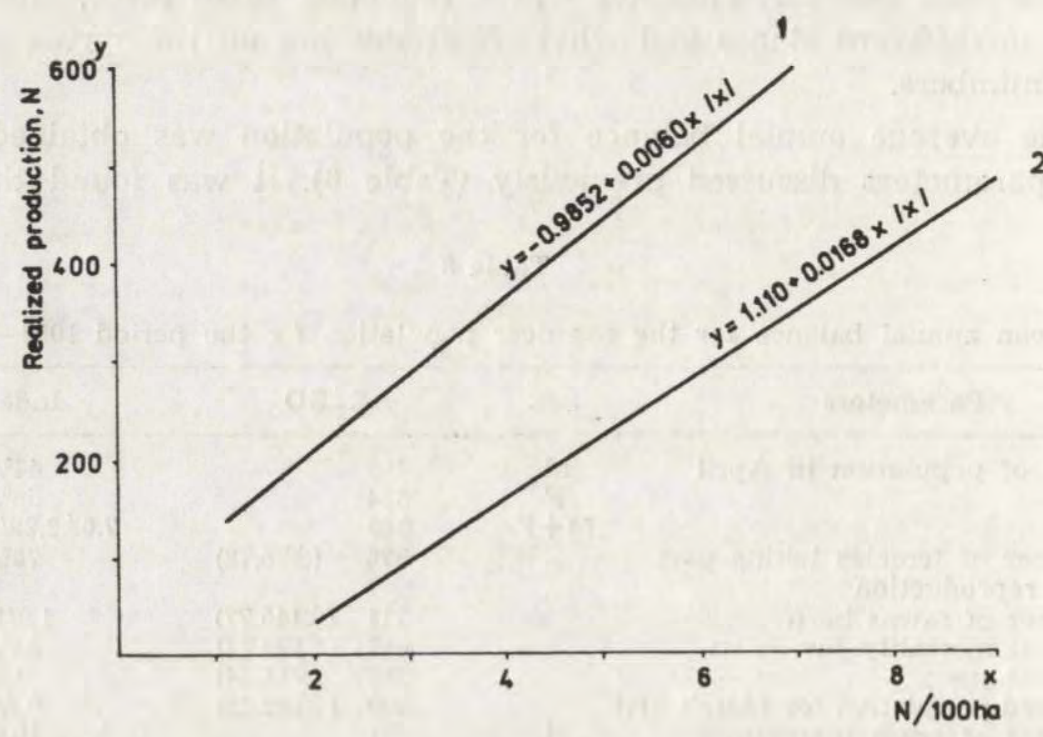

Fig. 10. Relation between effective production and density of the roe deer population. 1-for actual data, 2-for the expected values in the following years.

\section{DISCUSSION}

The results indicate lasting ties between the study population of roe deer and the field habitat. All the most important life functions of roe deer, relating inter alia to continuous stay over the whole year, consumption of food, from reproduction to death, were all recorded in this habitat.

The study roe deer population, despite considerable fluctuations in numbers, exhibits a trend to increase in numbers. In this respect it behaves entirely differently from populations of other animal species occupying field habitats, for which distinct annual fluctuations in numbers are characteristic (Andersen, 1952; Pielowski, 1975). This is 
due to the relatively high productivity of roe deer populations, which to a great degree depends on reproductive potential. Potential production (according to the number of embryos) in the Jutland Peninsula is $1.9 / \%$ (Strandgaard, 1972). Borg (1970) recorded a higher reproductive potential in Sweden (2.2 juv/\%) and Kurt (1968) lower in Switzerland (1.69), Stubbe (1979) in the German Democratic Republic (1.70), Szederjei (1971) in Hungary (1.55) and Fruziński and Eabudzki (1982) in western Poland (1.56). The opinion put forward by Szederjei (1971), that the value of potential reproductivity depends on habitat conditions in which the roe deer populations live, would appear correct.

Little is as yet known about the effect of the female's age on its fecundity. According to general data given by Strandgaard (1972), the percentage of females with one embryo is greatest among individuals aged 1.5 years. In other studies fecundity of females in different age classes has been determined on the basis of occurrence of corpora lutea the number of which, as Borg has shown (1970) is greater than the number of embryos. The results of the present study confirm that the fecundity of individuals in the older age classes decreases. It would seem that it is not this which is most important in the reproductivity of roe deer. In the population about $70 \%$ of the does give birth to two fawns and this is the reason for the relatively high reproductive potential of this species.

All data in literature point to the high mortality rate among young roe deer. Strandgaard (1972) states that there is from 0.5 to 1.6 fawns per each doe capable of reproduction, giving an average of 1.0. This author gives the large number of foxes as the chief cause of the high mortality at Kalø from 1967-1968, but does not give any definite data on this subject. In the German Democratic Republic from 1968-1970 realized production was from $0.7-0.82$ per female (Stubbe \& Passarge, 1979). According to Kurt (1968) the average realized production during the autumn period per female was 0.95 young, while Fruziński \& Łabudzki (1982) estimated realized production in a population of forest roe deer on a similar level. When examining, inter alia, realized production, by means of complete elimination, by shooting of roe deer in one of the shelterbelts in the Czempin experimental area (Pielowski \& Bresiński, 1982), the index of realized production was identical to that obtained in this study, i.e. 0.8 young reared per female of reproductive age. Minimum realized production among young animals which had survived their first winter, of only 0.12 fawns per female, was found for the Urals (Filonow, cited after Stubbe \& Passarge, 1979). This was due to the intense pressure on young animals by predators and the difficult climatic conditions for these animals. 
High mortality rate was found for the young roe deer in the study population also, the average figure for the period from birth to spring of the following year being $56 \%$. Effective increase varied in different years, from 0.1 to 1.4 , average 0.8 , per each female taking part in reproduction. The chief causes of such considerable losses are the climatic conditions differing from the normal in catastrophic years. Mechanization of agricultural operations is also an important factor here (Kałùziński, 1982). Predators, especially foxes, exert an important influence on reduction of young individuals.

There were also data, although not very exact, in literature on mortality among adult individuals. Among 77 individuals which disappeared from the experimental area in Denmark, in as many as $55 \%$ the cause was emigration, $17 \%$ was due to natural losses and $14 \%$ road accidents and disappearance without return information about individuals (Strandgaard, 1972). This author does not, however, give the extent of annual losses e.g. in one winter period. Stubbe (1963) gives an estimate of losses in herd of roe deer during the winter of $1962 / 63$, and states that in about $50 \%$ of cases mortality occurred among individuals in the first year of life and that it was high among the oldest roe deer and lowest in the middle age classes. He reached the conclusion that mortality increases together with increase in density, but does not explain the mechanism of occurrence of these increased losses in roe deer populations when weather conditions differ from normal. He does, however, suggest that the cause of greater losses should be considered as due to the long period of consuming frozen food, which may cause various inflammatory states in the alimentary tract.

Observations made during the winter of $1978 / 79$ may throw some light on the mechanism of the occurrence of such losses. Roe deer living in a field habitat are exposed to the effect, not only of low temperature and deep snow cover, but also to wind, which increases cooling. The dead roe deer were found in the position which they usually assume for resting and were in good condition. It may be assumed, with a considerable degree of probability, that death among a large number of young individuals and also weakened older animals took place as the result of freezing. In a forest habitat roe deer are usually able to shelter from wind, and consequently causes of winter losses among roe deer in woods are certainly different from those in fields. This may also be the reason why losses in head of roe deer were far lower $\left(33^{\%} \%\right)$ in the forest population during the catastrophic winter of 1978/79 (Fruziński \& Łabudzki, 1982).

In many roe deer populations, even when no shooting took place, females were found to predominate over males. Attention has been 
drawn to this problem by Strandgaard (1972), Nikoladie (1968), Prusaite et al. (1974), Pielowski \& Bresiński (1982), Fruziński \& Łabudzki (1982). Variations in sex structure in the population at Czempin were due only to a slight degree to selective shooting. Presumably the greater survival of females is of decisive importance in this case. The disproportion of young animals is particularly clearly evident. Similar results were obtained by Prior (1968) who found that the sex ratio among fawns from $1-3$ weeks old $(n=679)$ was $1: 1.3$ in favour of females. On the other hand Andersen (1953) found that the sex ratio at the age of $6-9$ years in the roe deer population he examined was $1: 3.5$ in favour of females. The sex ratio of $1: 1$ recommended in hunting practice is thus difficult to obtain, despite the influence exerted on sex structure by means of diversified shooting. It would seem that a sex ratio of $1: 1.2$ or $1: 1.3$ is a natural characteristic of roe deer populations (cf. also Fruziński \& Łabudzki, 1982a).

Table 9

Comparison of percentage of yearlings in different roe deer populations.

\begin{tabular}{|c|c|c|c|}
\hline Locality & $\begin{array}{l}\text { Percentage of } \\
\text { young } 1 \text { yr old }\end{array}$ & Remarks & Authority \\
\hline $\begin{array}{c}\text { Denmark } \\
, "\end{array}$ & $\begin{array}{l}50 \\
40\end{array}$ & $\begin{array}{l}\text { Total removal } \\
\text { Without hunting } \\
\text { pression }\end{array}$ & $\begin{array}{l}\text { Andersen, } 1953 \\
\text { Strangaard, } 1972\end{array}$ \\
\hline Poland, Czempiń & 30 & $\begin{array}{l}\text { Total removal, hunted } \\
\text { population }\end{array}$ & $\begin{array}{l}\text { Pielowski \& Bresiń- } \\
\text { ski, } 1982\end{array}$ \\
\hline Poland Zielonka & 42 & Hunted population & $\begin{array}{l}\text { Fruziński \& Eabudzki, } \\
1982\end{array}$ \\
\hline $\begin{array}{l}\text { Lithuania } \\
\text { Poland, Czempiń }\end{array}$ & $\begin{array}{l}34.5 \\
31\end{array}$ & $\begin{array}{l}\text { Hunted population } \\
\text { Field population, } \\
\text { exploited }\end{array}$ & $\begin{array}{l}\text { Blusma, } 1974 \\
\text { This paper }\end{array}$ \\
\hline
\end{tabular}

A knowledge of the age structure of a given roe deer population is important when planning the animals to be obtained by game shooting. Usually a theoretical structure is assumed for the different age classes, although it is deformed by natural mortality and differences in the number of individuals shot in different age classes. Table 9 gives a comparison of the proportion of yearlings in populations utilized, or not utilized, for game purposes, and also with complete elimination of a population from a given area. The proportion of yearlings obtained in this study is relatively low in the field roe deer population, but does not differ from certain other data given in literature. The higher values for the population from Denmark and from the west of Poland ( $\mathrm{Zie}$ lonka) refer to roe deer of lower age shot during the autumn period.

In addition to fawns, the most numerous group consists of individuals from the medium age classes $(4-5$ years old). This group is the most 
important to the population for two reasons: (1) it is characterized by greatest natality and lowest mortality, (2) it is most often subjected to most intensive pressure from game shooting, which is not favourable from the standpoint of rational population management.

Average length of individual life is in general short in roe deer populations. In the study population it was defined as 3.4 years. According to Andersen (1953) and Rieck (1970), average length of life of roe deer is about 2 years. The estimates given by Bobek et al. (1974) and Fruziński \& Łabudzki (1982b) are slightly higher, being respectively 2.4 and 2.9 years. Pielowski and Bresiński (1982), by means of complete elimination by shooting, estimated the average age of a roe deer population as 3.41 years. The relatively great survival of individuals in the study population may depend, inter alia, on relatively little game shooting.

In rational utilization of a population it is most important to keep ahead of mortality. Game shooting should be primarily directed towards the youngest and oldest individuals. Animals in these age classes are either not as yet reproductive, or are characterized by limited reproductivity and are subject to the greatest pressure at the time when the danger to the population from weather conditions increases. The relatively considerable shooting carried out from 1975 to 1976 is to some extent proof that utilization of this population should be carried out on a higher level than has been the case hitherto. In this way density can be maintained on an adequate level, with simultaneous use of the reproductive potential of the population, which is higher when density is lower. This problem has also been discussed in studies by Andrzejewski \& Jezierski (1967); Kurt (1968); Fruziński \& Łabudzki (1982b).

The quantitative annual balance for field roe deer populations, drawn up for fourteen years, provides some justification for finding that utilization of up to $20 \%$ of the spring numbers, with simultaneous preservation of age and sex structure, does not act unfavourably on the functioning of the population.

\section{REFERENCES}

1. Aitken R. J., 1975: Cementum layer and tooth wear as criteria for ageing roe deer (Capreolus capreolus). J. Zool., London, 175; 15-28.

2. Andersen J., 1952: Fluctuations in the field hare population in Denmark compared with certain climatic factors. Papers Game Res., 8: 41-43.

3. Andersen J., 1953: Analysis of a Danish roe-deer population. Danish Rev. Game Biol., 5: 127-155.

4. Andrzejewski R. \& Jezierski W., 1967: Ekologiczne problemy użytkowania i kierowania liczebnością populacji zająca na tle najnowszych polskich badań. Ekol. pol., B, 1: 16-34.

5. Bresiński W. \& Chlewski A., 1976: Tree stands in fields and spatial distribution of hare population. [In: "Ecology and management of European hare 
populations", Eds. Pielowski Z. \& Pucek Z.]. Państw. Wyd. Roln. i Leśne: 185-193. Warszawa.

6. Bresiński W., 1982: Grouping tendences in field-living roe deer under agrocenosis conditions. Acta theriol., 27: 427-447.

7. Blusma P. P., 1974: Sexual differencs and age changes of the weight and body size in Capreolus capreolus L. (Cervidae) in Lithuanian SSR. 1-st. Int. Theriol. Congress: 75, Moskwa.

8. Bobek B., Drożdż A., Grodziński W. \& Weiner J., 1974: Studies on productivity of the roe-deer population in Poland. XI int. Congr. Gam. Biol.: 115-123.

9. Borg K., 1970: On mortality and reproduction of roe-deer in Sweden during the period 1948-1969. Viltrevy, 7: 1-149.

10. Caughley G., 1977: Analysis of vertebrate populations. John Wiley: 1-232. London, New York.

11. Fruziński B. \& Eabudzki L., 1982a: Sex and age structure of a forest roe deer under hunting pressure. Acta theriol., 27: 377-384.

12. Fruziński B. \& Łabudzki L., 1982b: Demographic processes in a forest roe deer population. Acta theriol., 27: 365-375.

13. Kałuziński J., 1974: The occurrence and distribution of field ecotype of roe deer in Poland. Acta theriol., 19: 291-300.

14. Kałuziński J., 1978: Sarna (Capreolus capreolus L.) populacji polnej pod Czempiniem. Roczn. Akad. roln., Poznań C: 83-93.

15. Kałuziński J., 1982: Roe deer mortality due to mechanization of work in agrocenoses. Acta theriol., 27: 449-455.

16. Kurt F., 1968: Zusammenhänge zwischen Verhalten und Fortpflanzungleistung beim Reh (Capreolus capreolus L.). Z. Jagdwiss., 14: 97-106.

17. Nikoladie D., 1958: Okologische charakteristik der Rehpopulation in Distrikt Belje. Jelen, 7: 73-95. Beograd.

18. Pielowski Z., 1970: Sarna - Monografia przyrodniczo-łowiecka. Państw. Wyd. Roln. i Leśne: 1-120. Warszawa.

19. Pielowski Z., 1975: Charakterystyka ekologiczna populacji zająca Lepus europaeus Pallas 1778. Roczn. Akad. roln., Poznań, 65: 1-33.

20. Pielowski Z., 1977: Das Feldreh - Wild der Zukunft in der Agrar Landstschaft. Beitr. Jagd. und Wildforschung: 193-200.

21. Pielowski Z. \& Bresiński W., 1982: Population characteristics of roe deer inhabiting a small forest. Acta theriol., 27: 409-425.

22. Petrusewicz K., 1978: Osobnik, populacja, gatunek. Państw. Wyd. Nauk.: 1-384. Warszawa.

23. Prior R., 1968: The roe-deer of Granborne Chase. Oxford Univ. Press: 1-215. London.

24. Prusaite J. A., Blaschis A. S. \& Bakisis R. H., 1974: Reproduction intensity and population growth in Capreolus capreolus L. (Cervidae) in Lithuanian SSR. 1-st. Int. theriol. Congress: 87. Moskwa.

25. Rieck W., 1970: Alter und Gebissabnutzung beim Rehwild. Z. Jagdwiss., 4: 1-6.

26. Strandgaard H., 1972: An investigation of corpora lutea, embryonic development, and time of roe deer (Capreolus capreolus) in Denmark. Danish Rev. Game Biol., 6: 1-22.

27. Strandgaard H., 1972: The roe deer (Capreolus capreolus) population of Kalø and the factors regulating its size. Dannish Rev. Game Biol., 7: 1-204.

28. Stubbe Ch., 1963: Schalenwildverluste im Winter 1962/63. Z. Jagdwiss., 9: $121-124$. 
29. Stubbe Ch. \& Passarge H., 1979: Rehwild. VEB Deutscher Landwirtschaftsverlag.: $1-432$. Berlin.

30. Szederjei A. \& Szederjei M., 1971: Geheimnis des Weltrekordes - Das Reh. Teera:

31. Trojan P., 1978: Ekologia ogólna. Państw. Wyd. Nauk.: 1-418.

Accepted, August 2, 1982.

Jan KAEUZIŃSKI

\section{DYNAMIKA I STRUKTURA POPULACJI SARNY POLNEJ}

\section{Streszczenie}

W latach 1966-1980 w środowisku krajobrazu rolniczego o pow. 15 tys. ha przeprowadzono badania nad funkcjonowaniem populacji sarn. Celem badań było uzyskanie danych dotyczących dynamiki liczebności, rozrodu, śmiertelności, przeżywalności oraz struktury wieku i płci. Na podstawie zebranych danych sporządzono bilans ilościowy populacji. Podstawową metodą badań była szczegółowa ocena liczebności populacji wykonana poprzez bezpośrednie liczenie wszystkich osobników zasiedlających teren, na którym prowadzono badania.

Stwierdzono, że średnie zagęszczenie w ciągu czternastu lat wynosiło 7 osobników na 100 ha. Wyróżniono dwa okresy po sobie następujące, w których populacja systematycznie zwiększała swoją liczebność po czym następowal gwałtowny spadek liczebności. Bezpośrednią przyczyną zwiększonych upadków sarn były panujące w zimie niekorzystne warunki atmosferyczne. Zwiększanie liczebności w populacji było możliwe dzięki stosunkowo wysokiej rozrodczości jaką stwierdzono u tego gatunku, i średniej długości życia większej niż gdzie indziej.

Liczba urodzonych przypadająca na jedną samicę wynosi 1,9 mlodego. Wysoka jest jednak naturalna śmiertelność osobników mlodych i wynosi $56 \%$ liczby urodzonych. Jest to główny czynnik ograniczający przyrost zrealizowany. Srednio wynosi on 0,8 młodego na samicę biorącą udział w rozrodzie. Znacznie niższy jest, jeżeli odniesiony zostanie do wszystkich osobników żeńskich w populacji i wtedy wynosi 0,56 młodego na samice.

W populacji obserwowana była również wysoka śmiertelność osobników dorosłych. Srednia notowana była na poziomie $21 \%$ stanu wiosennego. Redukcja osobników w populacji w roku $1979 / 1980$ wyniosła około $51 \%$ i była najwyższa w ciągu calego okresu badań. W takich niekorzystnych okresach dla populacji giną przede wszystkim osobniki młodsze i najstarsze. Osobnik w populacji żyje około 3,5 roku. W ciągu całego okresu badań zauważalna była w populacji przewaga samic nad samcami i jest ona uwarunkowana wieloma czynnikami ekologicznymi. Grupe najliczniejszą stanowią w populacji osobniki młode, a udział jednorocznych wiosną w ciągu całego okresu badań średnio wynosi $31 \%$ stanu. Analizując roczny bilans ilościowy populacji stwierdzić należy, że średni roczny przyrost populacji w latach 1966-1980 jest nieznaczny gdyż $\Delta N=2 \%$. Niemniej jednak pozyskanie lowieckie przy zachowaniu właściwych struktur wynoszące $20 \%$ stanu wiosennego nie wplynie ujemnie na zachowanie się populacji.

Wszystkie te współzależności mające bezpośredni wpływ na zmiany liczebności w populacji działają na zasadzie sprzężenia zwrotnego między sposobem organizacji ekologicznej populacji a jej dynamiką líczebności. Istnieją bowiem $\mathbf{w}$ tej populacji mechanizmy, które zapobiegają zbytniemu rozmnożeniu oraz nadmiernemu spadkowi liczebności. 